\title{
PENDIDIKAN KRITIS DAN REKONSTRUKSI KURIKULUM MADRASAH
}

\author{
Hendri Purbo Waseso \\ Universitas Sains al-Qur'an (UNSIQ) Jawa Tengah di Wonosobo \\ hendrismp7yk@gmail.com
}

\begin{abstract}
This paper reveals the importance of the madrasah curriculum development through various contextual perspectives. Study of critical education occupies a position on a learner awareness efforts about the importance of continuity between theory and practice. Madrasah curriculum has a distinctive religions experienced difficulties in how religious subjects functioning integrative and relevant to the present conditions. Through literature review, it was found that the critical education can be used as an alternative in reconstructing the existing of madrasah curriculum. Critical education gives a basic framework and substantial how egalitarian, humanist education, and transformative it can be implemented. It is done with the four principles in the process of reconstruction of the madrasah's curriculum, namely to minimize the gap between theory and practice in the sphere of organizing material, growing the awareness of educators and learners become critical educators and critical learners that achieved together, lead learners to realize the potential significantly, and the transmission of Islamic values through a hidden curriculum.
\end{abstract}

Keywords: Madrasah Curriculum and Critical Education 


\section{A. Pendahuluan}

Pendidikan Islam sebagai bagian dari pendidikan nasional semakin menguat. Setidaknya, kebijakan-kebijakan pendidikan yang telah dirumuskan sampai saat ini dapat menjelaskan bagaimana pendidikan Islam menempati posisi signifikan dalam upaya mencerdaskan generasi bangsa. Berdasarkan statistik, jumlah madrasah tidak kurang dari $18 \%$ dari seluruh jumlah lembaga pendidikan di Indonesia. ${ }^{1}$ Artinya madrasah sebagai salah satu lembaga pendidikan Islam tidak layak dipandang sebelah mata dalam perannya meningkatkan kualitas sumber daya manusia Indonesia.

Sebagai bagian dari pendidikan nasional, pendidikan Islam selalu tawadlu dalam hal kebijakan yang ada. Hal tersebut jelas terlihat dari pengelolaan madrasah yang berada dibawah kementerian agama, sedangkan inisiator utama produksi kebijakan pendidikan berada dibawah kementerian pendidikan dan kebudayaan. Sederhananya, bahwa madrasah akan selalu siap menerima kewajiban baik secara substansial maupun prosedural bagaimana pendidikan itu harus dijalankan yang datang dari kemendikbud, salah satunya adalah kurikulum 2013. Artinya kurikulum 2013 sebagai bentuk kebijakan pendidikan nasional, madrasah memiliki kewajiban untuk menerapkannya.

Terlepas dari pro dan kontra implementasi kurikulum 2013, madrasah memiliki ciri khas tersendiri dalam pengembangan kurikulumnya. Setidaknya, muatan pengetahuan agama Islam dapat menjadi ciri pembeda jika dibandingkan dengan kurikulum sekolah umum. Pengetahuan agama Islam dalam madrasah dimaksudkan untuk membekali peserta didiknya agar mampu memahami serta menerapkan ajaran Islam sesuai dengan sumber-sumber ajaran Islam. Dengan maksud tersebut, pengembangan kurikulum madrasah yang disesuaikan dengan kondisi sosial masyarakat dan pemikiran yang sedang berkembang menjadi penting untuk dilakukan.

Pengembangan kurikulum madrasah sesuai dengan batasan-batasannya seharusnya mampu berbuat banyak. Lebih spesifik, kurikulum madrasah sangat memungkinkan untuk terbuka dengan berbagai perspektif dengan tetap menjaga prinsip-prinsipnya sebagai lembaga pendidikan yang khas Islam. Pendidikan kritis agaknya dapat menjadi salah satu perspektif dalam pengembangan kurikulum madrasah sehingga tranformasi nilai-nilai dasar Islam dapat diaktualisasikan.

Pendidikan kritis sebagai perspektif memungkinkan proses pendidikan Islam yang dilaksanakan menjadi semakin berorientasi pada nilai-nilai keadilan secara nyata. Secara epistemologis, Toto Suharto mengungkapkan bahwa pendidikan kritis tidak bertentangan dengan ajaran normatif Islam sebagai agama rahmat bagi seluruh alam. ${ }^{2}$ Prinsip-prinsip humanisasi, relasi teori dan praktik, analisis untuk melihat segala bentuk penindasan dalam pendidikan kritis sangat sesuai dengan semangat ajaran Islam. Prinsip-prinsip tersebut mengacu pada bagaimana keadilan dapat terjadi dan dirasakan oleh seluruh umat manusia.

1 Balitbangdiklat.kemenag.go.id., tanggal akses 10 Oktober 2014

2 Toto Suharto, "Pendidikan Kritis Dalam Prespektif Epistemologi Islam", Paper dipresentasikan dalam acara AICIS 2012 di IAIN Sunan Ampel Surabaya. 
Dalam tulisan ini, pendidikan kritis hendak diposisikan sebagai tawaran untuk mengatasi problem-problem dalam proses pelaksanaan pendidikan Islam yang terfokus pada kurikulum madrasah sehingga dapat dijelaskan seberapa jauh pendidikan kritis memberikan kontribusi terhadap kurikulum madrasah. Karena itu, tulisan ini hendak mengkaji pengembangan secara teoritik mengenai kurikulum madrasah berdasarkan asumsi-asumsi utama dalam wacana pendidikan kritis. Sejauh ini, kajian mengenai kurikulum hanya berkutat pada dua tema, yaitu studi kurikulum dengan menggunakan pendekatan pedagogis yang menekankan pada aspek teknis-instrumental dalam bentuk implementasi kurikulum dalam proses pembelajaran dan studi kurikulum dilakukan dalam tema sekitar hidden curriculum. ${ }^{3}$ Selain dua tema tersebut, pengkaitan antara kurikulum madrasah dengan kajian pendidikan kritis masih relatif sepi peminat.

Misalnya, studi kurikulum pendekatan pedagogis yang dilakukan oleh Mulyani Mudis Taruna berjudul "kontribusi madrasah dalam penguatan kurikulum 2013" yang mengkaji mengenai persiapan madrasah dalam implementasi kurikulum 2013. ${ }^{4}$ Artinya, bahwa kurikulum madrasah cenderung mengekor pada kurikulum sekolah tanpa ada pengembangan secara kritis dan transformatif. Selain itu, umumnya kurikulum madrasah diteliti dari aspek implementasinya.

Kajian yang agak berdekatan adalah studi yang dilakukan oleh Toto Suharto berjudul "pendidikan kritis dalam prespektif epistemologi Islam" menemukan bahwa prinsip dasar pendidikan kritis yang terdiri dari humanisasi, analisis hegemoni untuk melihat segala bentuk penindasan, konsep intelektual transformatif dan praksis tranformasi yang merelasikan antara teori dan praktik, sejatinya sejalan dengan ajaran normativitas Islam sebagai agama rahmat bagi semua lingkungan. ${ }^{5}$ Namun demikian, Toto belum mengungkap kajian pendidikan kritis sampai pada kajian teoritik mengenai kurikulum.

Pada posisi inilah, pengkaitan antara pendidikan kritis dengan kurikulum madrasah masih sangat minim. Dengan demikian, tulisan ini diharapkan dapat melengkapi kajian yang telah dilakukan sebelumnya.

Untuk mensistematisasi tulisan ini, terdapat tiga pembahasan utama yaitu, asumsi-asumsi dari pendidikan kritis, bentuk kurikulum madrasah saat ini, dan signifikansi pendidikan kritis jika dikaitkan dengan kurikulum madrasah 2013. Melalui kajian pustaka, pendidikan kritis dan kurikulum madrasah dideskripsikan terlebih dahulu sehingga dapat ditarik signifikansi pendidikan kritis dalam kurikulum madrasah 2013.

\section{B. Pendidikan Kritis}

Pendidikan kritis menurut Freire sebagaimana dikutip Toto Suharto adalah suatu bentuk

3 Rakhmat Hidayat, "Kurikulum Sebagai Arena Kontestasi Kekuasaan: Konseptualisasi Gagasan Michael Apple Hingga Pierre Bourdieu”, Jurnal Komunitas, Volume 3, 1 Februari 2009.

4 Mulyani Mudis Taruna, "Kontribusi Madrasah dalam Penguatan Kurikulum 2013 (studi tentang kesiapan madrasah dalam pelaksanaan kurikulum 2013 di Jawa Tengah)", Analisa Journal of Social Science and Religion, Volume 22 No. 01 June 2015.

5 Toto Suharto, "Pendidikan Kritis Dalam Prespektif Epistemologi Islam", Paper dipresentasikan dalam acara AICIS 2012 di IAIN Sunan Ampel Surabaya. 
pedagogi yang harus diolah bersama, bukan untuk, the oppressed (sebagai individu maupun anggota masyarakat secara keseluruhan) dalam perjuangan tanpa henti untuk merebut kembali kemanusiaan. ${ }^{6}$ Pendidikan kritis menginginkan suatu bentuk kebebasan dari segala belenggu yang bersifat menindas. Komitmen untuk selalu berjuang melalui media pendidikan menjadi keharusan dalam pandangan pendidikan kritis. Pendidikan kritis yang diintrodusir oleh Paulo Freire mendapat sambutan luar biasa dalam dunia pendidikan diberbagai Negara dikarenakan konsepnya yang mampu membangkitkan kesadaran kaum pinggiran. Keefektifan pendidikan kritis dalam merevisi pendidikan konservatif terwujud dalam berbagai bentuk keadilan sosial sehingga pendidikan kritis secara teoritik mendapat perhatian besar dan dijadikan subjek pengetahuan yang layak untuk dikembangkan. Beberapa tokoh pasca Freire seperti Henry Giroux, Michael Apple, McLaren dan nama-nama lainnya ikut andil dalam pengembangan konsep pendidikan kritis.

Henry Giroux dalam bukunya yang berjudul Critical Pedagogy, Cultural Politics, and the Discourse of Experience menjelaskan beberapa prinsip pendidikan kritis yaitu, pertama, semakin terbukanya manusia (murid) terhadap dunia sehingga dalam maknanya yang luas pendidikan merupakan proses belajar untuk menyesuaikan diri seseorang murid dengan dunianya serta membangun dunia dan kebudayaannya. Kedua, murid diletakkan sebagai makhluk budaya, sehingga pendidikan tidak melulu mengajarkan ilmu dan teknologi tetapi juga harus membantu mengembangkan kompetensi murid dalam penguasaan lingkungan, komunikasi dan kritik. Ketiga, murid diletakkan sebagai manusia historis sehingga pendidikan hendaknya: (1) menghindari sikap dogmatis karena bertentangan dengan sifat historis pengetahuan manusia, (2) menghindari tekanan yang berlebihan pada produk, tetapi juga menekankan pentingnya proses pendidikan, dan (3) membangun kembali akar-akar historis pada kesadaran murid berkaitan dengan sejarah dari problem-problem kontemporer. Keempat, murid diletakkan pada dimensi spiritual-transenden. Hal ini berarti pendidikan tidak melulu melatih aspek nalar murid tetapi juga menyentuh aspek-aspek spiritual-transenden yang irrasional.

Dalam pandangan McLaren, pendidikan kritis secara revolusioner menggunakan dunia secara reflektif untuk mewujudkan praxis transformasi pengetahuan melalui kritik epistemologis. Kritik epistemologis bertujuan bukan hanya untuk membongkar representasi-representasi pengetahuan, tapi juga untuk mengeksplorasi bagaimana dan mengapa produksi pengetahuan representasi itu terjadi. Dengan kata lain, pendidikan kritis tidak hanya meneliti isi pengetahuan tapi juga metode produksinya. ${ }^{7}$ Melalui kritik epistemologis tersebut, Mclaren sebenarnya mengidealkan produksi pengetahuan yang dapat diperankan oleh baik peserta didik maupun pendidik bersama-sama.

Sedangkan menurut H.A.R Tilaar, prinsip penting pendidikan kritis yang dipengaruhi oleh mazhab Frankfurt adalah sebagai berikut:

1. Pemberdayaan kelompok-kelompok yang termarginalisasi oleh sistem kekuasaan dan ekonomi yang didominasi oleh kelompok yang berkuasa. 
2. Mengkritik sistem pendidikan yang dipengaruhi oleh politik ekonomi yang secara sadar atau tidak sadar memberikan privilege kepada peserta didik ekonomi kuat.

3. Ilmu pengetahuan bukanlah bebas nilai tetapi merupakan rekonstruksi dalam suatu masyarakat. Sistem kekuasaan dalam masyarakat menurut Foucault menghasilkan rekonstruksi ilmu pengetahuan yang terikat dengan kepentingan dari kelompok yang berkuasa. Bukan hanya ilmu pengetahuan tetapi juga berbagai hubungan masyarakat termasuk masalah-masalah seksual juga dipengaruhi oleh sistem kekuasaan tersebut.

4. Pendidikan yang benar adalah bukan merupakan suatu transmisi kebudayaan yang pada hakikatnya dikuasai oleh kelompok-kelompok yang berkuasa.

5. Prinsip hegemoni yang dikemukakan oleh Gramsci dapat digunakan oleh pendidik dalam menghadapi masalah-masalah asimetris di dalam kekuasaan serta hubungan-hubungan social lainnya dalam masyarakat yang dikuasai kelas berkuasa.

6. Prinsip perlawanan terhadap hegemoni dari kelompok berkuasa. Pendidikan dapat memberikan alat tanpa revolusi dalam melawan ketidakadilan dalam masyarakat.

7. Praksis: aliansi antara teori dan praktik. Prinsip ini dikembangkan oleh Paulo Freire yang menghubungkan antara individu dengan objek yang dipelajarinya. Dengan adanya kesatuan antara teori dan praktik maka pendidikan akan langsung berhubungan dengan prioritas. Dengan kata lain verbalisme akan dapat dihilangkan dari proses pendidikan karena teori langsung dikaitkan dengan praktik.

8. Dialog dan penyadaran. Dialog mengimplikasikan adanya pemberdayaan sedangkan pemberdayaan itu sendiri berarti lahirnya kesadaran akan kemampuan seseorang baik kelebihannya maupun kelemahannya. Prinsip inilah yang terkenal dalam gerakan pemberdayaan Paulo Freire "conscientizacao". ${ }^{8}$

Sumbangan Apple terhadap konsep pendidikan kritis menekankan pada pentingnya perumusan sebuah kurikulum. Menurut Apple, kurikulum pendidikan bukan hanya menekankan pada academic achievement, tapi lebih diarahkan pada pembangunan aspek epistemologis, politis, ekonomis, ideologis, teknis, estetika, etis, dan historis. Oleh karena institusi sekolah merupakan arena produksi budaya, maka penggunaan konsep hegemoni dan ideologi sebagai pisau analisis dalam pendidikan kritis merupakan hal esensial. Analisis dengan menggunakan konsep hegemoni dan ideologi ini dimaksudkan untuk dapat mengungkap nilainilai hegemonik-ideologis yang terkandung dalam hidden curriculum.

Dari beberapa pokok pikiran para tokoh pengembang pendidikan kritis, pada dasarnya pendidikan kritis menginginkan institusi pendidikan menjadi gerbang awal bagi pemberdayaan masyarakat yang mendapat perlakuan tidak adil. Kesetaraan dan keadilan manusia dalam bermasyarakat dari berbagai bidang kehidupan menjadi motivasi kuat dari pentingnya mewujudkan pendidikan sebagai media transformasi sosial. Sebagai sebuah perspektif, pendidikan kritis sangat mungkin diinkorporasikan dalam kurikulum madrasah.

8 H.A.R. Tilaar, Pedagogik Kritis; Perkembangan, Substansi, dan Perkembangannya di Indonesia (Jakarta: Rineka Cipta, 2011), hlm. 21-22. 


\section{Kurikulum Madrasah}

Kurikulum madrasah merupakan suatu perangkat yang digunakan oleh madrasah dalam menjalankan fungsinya sebagai lembaga pendidikan. Sebagai suatu perencanaan, kurikulum madrasah berisi tentang tujuan pendidikan, bahan ajar, metode dan strategi, dan evaluasi. Komponen-komponen kurikulum madrasah tersebut saling terkait satu sama lain. Keterkaitan antar komponen tersebut dimaksudkan untuk tercapainya suatu tujuan pendidikan tertentu.

Secara historis, kurikulum yang digunakan sejak berdirinya madrasah mengacu pada lembaga pendidikan modern. Hal ini memang sesuai dengan salah satu maksud awal dari berdirinya madrasah yaitu sebagai penghubung lulusan para lulusan pesantren dengan dunia kerja. Mengingat, pesantren tidak menyediakan ijazah formal yang berlaku di dunia kerja sehingga madrasah menjadi lembaga pendidikan yang menyatukan dua model pendidikan sekaligus, pesantren dan sekolah. Dalam proses pengadopsian model sekolah, madrasah kemudian memiliki legitimasi untuk mengantarkan lulusannya pada dunia kerja dimana sebagian besar peserta didiknya adalah santri. Selain itu, internalisasi nilai-nilai universal Islam yang termanifestasi dalam akhlak peserta didiknya juga menjadi ghirah dari kurikulum madrasah sebagai lembaga pendidikan berciri khas Islam.

Dalam perjalanan kurikulum madrasah, beberapa ahli pendidikan Islam melihat banyak kelemahan. Towaf menilai kurikulum madrasah masih terdapat jurang antara materi yang dipelajari dengan dunia keseharian peserta didik. Senada dengan Towaf, Amin Abdullah juga menyoroti kurikulum yang ada sekarang lebih banyak terkonsentrasi pada persoalanpersoalan teoritis keagamaan yang bersifat kognitif. Sedangkan Komarudin Hidayat melihat kelemahan dari orientasi kurikulum dan materinya yaitu orientasi kurikulum lebih pada belajar tentang agama, sehingga yang terjadi adalah ketimpangan antara pengetahuan yang dimiliki dengan perilaku yang dimiliki. Sedangkan materi yang ada masih belum tersusun dan terpilah dengan tepat sehingga banyak materi dasar yang seharusnya dipelajari menjadi terlewatkan. ${ }^{9}$ Kelemahan dalam kurikulum madrasah tersebut tentunya berdampak pada kualitas lulusan yang dihasilkan.

Kelemahan dari berbagai komponen dalam kurikulum madrasah menuntut adanya penyelesaian yang efektif. Jika dilihat dari kebijakan pendidikan nasional, birokrat pendidikan Islam sekaligus sebagai ahli pendidikan Islam berusaha membuat terobosanterobosan baru bagaimana agar kualitas madrasah dapat terwujud. Malik Fajar sebagai ahli pendidikan Islam sekaligus mantan menteri agama mengusulkan bahwa kebijakan kebijakan pengembangan madrasah perlu mengakomodasi tiga kepentingan. Kepentingan pertama adalah bagaimana kebijakan itu pada dasarnya harus memberi ruang tumbuh yang wajar bagi aspirasi utama umat Islam. Yakni, menjadikan madrasah sebagai wahana untuk membina ruh atau praktik hidup keislaman. Dengan jargon santri dapat kita katakan bahwa madrasah didirikan untuk menanamkan dan menumbuhkan akidah Islamiah putra-

9 Hujair AH. Sanaky, Paradigma Pendidikan Islam; Membangun Masyarakat Madani Indonesia, (Yogyakarta: Safiria Insania Press, 2003), hlm. 165-166. 
putri umat Islam dan bangsa. Lebih dari itu, diharapkan agar madrasah dapat melahirkan golongan terpelajar yang bisa menjalankan peran tafaqquh fid din.

Kepentingan kedua adalah bagaimana kebijakan itu memperjelas dan memperkukuh keberadaan madrasah sebagai ajang membina warga negara yang cerdas, berpengetahuan, berkepribadian, serta produktif, sederajat dengan sistem sekolah. Porsi dari kebijakan ini tidak lain agar pendidikan madrasah sanggup mengantarkan peserta didik memiliki penguasaan the basic secara memadai, yaitu penguasaan pengetahuan dan kemampuan dasar bidang bahasa, matematika, fisika, kimia, biologi, ilmu pengetahuan sosial dan pengetahuan kewarganegaraan. Madrasah juga merpakan tempat persemaian yang baik untuk menumbuhkan kreativitas seni, serta juga sebagai tempat berlatih dalam mengembangkan ketrampilan bekerja.

Kepentingan ketiga adalah bagaimana kebijakan itu bisa menjadikan madrasah dapat merespon tuntutan-tuntutan masadepan. Untuk itu, madrasah perlu diarahkan kepada lembaga yang sanggup melahirkan sumber daya manusia yang memiliki kesiapan memasuki era globalisasi, era industrialisasi ataupun era informasi. Secara kultural, tugas ini bisa sangat menegangkan sebab tuntutan masa depan terkadang mengancam segmen dasar institusi yang memiliki kepentingan keagamaan. ${ }^{10}$ Pengakomodasian tiga kepentingan tersebut dalam konteks kurikulum madrasah sangat efektif jika dapat diterjemahkan ke dalam proses pendidikan madrasah secara nyata.

Seiring dengan bergulirnya kebijakan baru kurikulum 2013, kurikulum madrasah melakukan adaptasi-adaptasi dalam berbagai komponennya. Adaptasi tersebut merupakan konsekuensi dari kesamaan posisi madrasah dengan sekolah dalam UU Sisdiknas No 20 tahun 2003. Seperti diketahui bahwa kurikulum 2013 mengandalkan konsep pembelajaran saintifik dan penilaian autentik yang harus diterapkan dalam proses pembelajaran yang dilakukan. Madrasah secara otomatis juga dituntut untuk mengimplementasikannya. Walhasil, kurikulum madrasah 2013 memiliki wajah yang cukup meyakinkan jika mampu menerapkan pembelajaran saintifik dan penilaian autentik. Tantangan nyatanya adalah bagaimana implementasi kurikulum 2013 tersebut pada beberapa matapelajaran keagamaan baik di MI, MTs, maupun MA. Pasalnya, mata pelajaran agama yang terdiri dari al-Qur'an Hadist, Akidah-Akhlak, Fikih, dan SKI tidak begitu mengenal proses pembelajaran saintifik. Secara konseptual memang mungkin untuk diterapkan, namun secara praktik banyak hal yang perlu dicari operasionalisasinya.

\section{Kontribusi Pendidikan Kritis dalam Kurikulum Madrasah 2013}

Dalam rangka memperkuat secara teoritik-praktik, pendidikan kritis cukup relevan jika dikaitkan dengan kurikulum madrasah 2013. Implementasi kurikulum madrasah jika mempertimbangkan saran-saran dari pendidikan kritis memungkinkan rekonstruksi kurikulum madrasah menjadi lebih hidup dan berdaya aktual tinggi. Kedudukan dan pengakuan yang sama antara peserta didik dan pendidik dalam berinteraksi inilah yang akan lebih menghidupkan proses pembelajaran. Berdaya aktual tinggi ditafsirkan dengan selalu terkontekstualisasikannya materi yang dipelajari oleh peserta didik dengan kehidupan langsung.

10 A. Malik Fadjar, Madrasah dan Tantangan Modernitas, (Bandung: Mizan, 1998), hlm. 31-32 
Kontribusi pendidikan kritis dalam pengembangan kurikulum madrasah 2013 setidaknya dapat dikerucutkan menjadi empat hal. Pertama, pengorganisasian materi dalam setiap mata pelajaran memungkinkan untuk dirombak ulang berdasarkan karakteristiknya sehingga materi yang dipelajari peserta didik tidak tampak ambivalen dengan kehidupan nyata. Hal tersebut akan mengurangi bahkan menghapus kesenjangan antara teori dan praktik. Kesatuan antara teori dan praktik yang menjadi salah satu tema penting dalam pendidikan kritis memungkinkan materi dalam mata pelajaran agama menjadi terintegrasi secara langsung dengan dunia yang dihadapi peserta didik. Misalnya materi iman kepada Allah dalam mata pelajaran akidah tidak hanya berbicara mengenai apa dan bagaimana, tetapi langsung dihadapkan dengan situasi yang dialami peserta didik dengan cara dialog. Begitu juga dengan materi-materi lain dalam mata pelajaran agama di madrasah. Secara singkat dapat dijelaskan bahwa pembelajaran diawali dari dunia peserta didik, bukan dunianya si pendidik.

Kedua, pendidik bertugas untuk mengorganisasikan dan mengarahkan agar materi yang dipelajari peserta didik tidak tampak ambivalen. Begitulah idealisasi pendidik versi pendidikan kritis. Fungsi pendidik tidak lebih sebagai orang yang ingin mengajak untuk menyadari akan dunia sesuai dengan apa yang dilihat oleh masing-masing peserta didik. Tujuan utamanya adalah agar peserta didik dapat beraktualisasi tanpa hambatan apapun dan mampu memahami dirinya sendiri sebagai manusia sejati. Asumsi bahwa pendidik tidak lebih pintar dari peserta didik menjadi syarat awal bagi pendidik kritis. Pendidik kritis harus melepaskan dan mengendalikan pengetahuannya agar tidak mematikan apa yang dipahami oleh peserta didik. Pendidik kritis harus membebaskan peserta didiknya untuk menentukan sendiri pilihan-pilihan mana materi yang penting untuk dipelajari bagi dirinya. Jika pendidik kritis ini menjadi rujukan dari idealisasi pendidik Islam, sangat mudah ditebak bahwa peserta didiknya akan dapat melihat potensipotensinya sendiri sehingga mereka tidak akan canggung dalam menghadapi dunia nyata dan pada akhirnya lulusan madrasah tidak dipandang sebelah mata atau mampu bersaing dengan lulusan non-madrasah.

Ketiga, evaluasi dalam kurikulum madrasah sebagai cara untuk mengukur keberhasilan dari proses pendidikan dapat dikatakan berhasil ketika peserta didik dapat berkata "kini saya terheran-heran pada diri saya sendiri". Ungkapan tersebut diambil dari salah satu peserta program pemberantasan buta huruf oleh Paulo Freire. ${ }^{11}$ Ungkapan tersebut dapat ditafsirkan sebagai pernyataan yang menunjukan ketakjuban. Bahwa ketidakmungkinan yang selama ini dibayangkan menjadi lenyap. Potensi-potensi yang teraktualisasikan menjadi penyebab dari keterherannya akan dirinya. Ungkapan tersebut dapat dijadikan indikator dalam melihat seberapa jauh proses pendidikan itu efektif dan berdaya guna bagi peserta didiknya. Artinya, evaluasi yang digunakan dalam kurikulum madrasah pun seharusnya mampu membuat peserta didik menjadi terheran-heran akan dirinya sendiri.

Penilaian autentik dalam kurikulum 2013 mengamanatkan kesinambungan proses dan penilaian yang dilakukan untuk mencapai standar kompetensi lulusan yang telah ditentukan. Dalam rangka menghadirkan kesadaran peserta didik akan potensinya sendiri, dengan mengacu 11 Paulo Freire, Pendidikan Sebagai Praktek Pembebasan, (Jakarta: Gramedia, 1984), hlm. 43. 
pada proses pembelajaran yang dialogis, penilaian dalam kurikulum madrasah 2013 harus diarahkan pada penilaian yang sebenar-benarnya. Penilaian yang mengacu pada keseimbangan antara aspek kognitif, sikap dan psikomotorik melalui teknik kuantitatif-kualitatif akan efektif dan dianggap sesuai jika peserta didik secara jujur dan objektif merasakan perubahan yang dialaminya.

Keempat, hidden curriculum madrasah. Selama ini, madrasah memiliki perbedaan khas dengan sekolah dari sisi konten materi agama yang dipelajari peserta didik. Materi umum pada madrasah tidak berbeda dengan materi umum pada sekolah. Karena itu, madrasah sebenarnya berperan penting dalam mentransformasikan nilai-nilai moral-etika yang bersumber dari Islam dan peran ini bukan fungsi utama dari sekolah.

Dalam fungsi transformasi nilai-nilai Islam, hidden curriculum sangat efektif jika dimaksimalkan oleh guru di Madrasah. Menurut Henry Giroux, hidden curriculum merupakan sesuatu yang tidak tertulis seperti norma, nilai, kepercayaan, yang melekat serta ditransmisikan kepada murid berdasarkan aturan yang mendasari struktur rutinitas dan hubungan sosial di sekolah dan ruang kelas. ${ }^{12}$ Dalam kerangka hidden curriculum versi Giroux ini, guru dapat secara individual maupun kerjasama merancang transmisi nilai-nilai Islam dalam suatu bentuk aktivitas sekolah ataupun program kelas.

\section{E. Penutup}

Deskripsi dan pembahasan tentang kontribusi pendidikan kritis dalam kurikulum madrasah di atas dapat diambil beberapa intisari pemikiran. Pertama, kurikulum madrasah masih perlu membuka diri dengan berbagai perspektif. Hal tersebut mendesak untuk dilakukan jika dikaitkan dengan problem-problem madrasah sekarang misalnya rendahnya mutu lulusan madrasah. Kedua, pendidikan kritis memberi kerangka dasar dan substansial bagaimana pendidikan yang humanis, egaliter, dan transformatif dapat dilaksanakan secara nyata. Ketiga, kontribusi pendidikan kritis dalam rekonstruksi kurikulum madrasah mencakup empat hal yaitu, meminimalisir kesenjangan antara teori dan praktik dalam ranah pengorganisasian materi, menumbuhkan kesadaran pendidik dan peserta didik sehingga menjadi pendidik kritis dan peserta didik kritis yang dicapai secara bersama-sama, mengantarkan peserta didik untuk menyadari potensi-potensinya secara nyata, dan transmisi nilai-nilai Islam melalui hidden curriculum.

12 Rakhmat Hidayat, Pengantar Sosiologi Kurikulum (Jakarta: Rajawali Press, 2011), hlm. 80. 


\section{Bibliography}

Balitbangdiklat.kemenag.go.id., tanggal akses 10 Oktober 2014.

Fadjar, A. Malik. (1998). Madrasah dan Tantangan Modernitas. Bandung: Mizan.

Freire, Paulo. (1984). Pendidikan Sebagai Praktek Pembebasan. Jakarta: Gramedia.

Hidayat, Rakhmat. (2011). Pengantar Sosiologi Kurikulum. Jakarta: Rajawali Press.

Sanaky, Hujair AH. (2003). Paradigma Pendidikan Islam; Membangun Masyarakat Madani Indonesia. Yogyakarta: Safiria Insania Press.

Suharto, Toto, "Pendidikan Kritis Dalam Prespektif Epistemologi Islam”, Paper dipresentasikan dalam acara AICIS 2012 di IAIN Sunan Ampel Surabaya.

Tilaar, H.A.R. (2011). Pedagogik Kritis; Perkembangan, Substansi, dan Perkembangannya di Indonesia. Jakarta: Rineka Cipta.

Rakhmat Hidayat, "Kurikulum Sebagai Arena Kontestasi Kekuasaan: Konseptualisasi Gagasan Michael Apple Hingga Pierre Bourdieu”, Jurnal Komunitas, Volume 3, 1 Februari 2009.

Mulyani Mudis Taruna, "Kontribusi Madrasah dalam Penguatan Kurikulum 2013 (studi tentang kesiapan madrasah dalam pelaksanaan kurikulum 2013 di Jawa Tengah)”, Analisa Journal of Social Science and Religion, Volume 22 No. 01 June 2015. 